\title{
Could beta blocker use in elderly hypertensive patients reduce risk of skin cancers?
}

\section{Yaşlı hipertensif hastalarda kullanılan beta blokerler cilt kanserlerinin riski azaltır mı?}

\author{
(1) Habibullah Aktaş, ${ }^{1}$ (1) Erdinç Terzi ${ }^{2}$ \\ 'Department of Dermatology, Karabük Training and Research Hospital, Karabük, Turkey \\ ${ }^{2}$ Department of Dermatology, İstinye University Liv Hospital, İstanbul, Turkey
}

\begin{abstract}
Introduction: Beta blockers are commonly used medications mainly in the treatment of cardiovascular health problems for years. Other known indications are migraine, anxiety, thyrotoxicosis and infantile hemangiomas. In addition to these, recent studies showes they have anticancer properties. We aimed to investigate possible preventive effect of beta blockers in the occurrence of nonmelanoma skin cancers in elderly hypertensive patients.

Methods: The study included 318 patients over the age of fifty and who have been using medication at least for two years. The data were obtained between May 2016-June 2018. Nonusers patients were admitting to the same clinic for another dermatological reason. Patients using more than one antihypertensive were classified in the beta blocker group if they use beta blocker. Gender, age, skin diagnosis and types of drugs were noted and compared with statistically. Results: 318 patients were assessed, 157 (49.4\%) were male, 161 $(50.6 \%)$ were female. Average age of patients was $72.5 .73 \%$ of beta blocker group had no skin lesion. This rate was $39.5 \%$ and $21.6 \%$ for other antihyperrtensive agents group and non-user group respectively.

Discussion and Conclusion: Patients using beta-blockers were less likely to have solar keratoses and nonmelanoma skin cancers. Preventive effect of beta blocker type antiypertensive agents against skin carcinogenesis was demonstrated in this retrospective observational study.
\end{abstract}

Keywords: Beta blockers; nonmelanoma skin cancer.

A ctinic keratosis and non melanoma skin cancers are generally seen in elderly people. Skin aging and ultraviolet exposure are known to increase the frequency of these diseases. ${ }^{[1]}$ Although there are small exceptions, it can be stated that more
Özet

Amaç: Beta blokerler genellikle kardiyovasküler sağlık sorunlarının tedavisinde kullanılan ilaçlardır. Diğer bilinen endikasyonları migren, anksiyete, tirotoksikoz ve infantil hemanjiyomlardır. Bunlara ek olarak, son zamanlarda yapılan çalışmalarda antikanser özelliklere sahip oldukları gösterilmiştir. Yaşlı hipertansif hastalarda beta blokerlerin melanom dışı deri kanserleri oluşumunda olası koruyucu etkisini araştırmayı amaçladık.

Gereç ve Yöntem: Çalışmaya elli yaş üstü ve en az iki yıldır ilaç kullanan 318 hasta dahil edildi. Veriler Mayıs 2016-Haziran 2018 tarihleri arasında elde edildi. Hiç ilaç kullanmayan hastalar aynı kliniğe başka bir dermatolojik nedenden ötürü gelenlerden seçildi. Birden fazla antihipertansif kullanan hastalar beta bloker kullanıyorlarsa, beta bloker grubunda yer aldı. Cinsiyet, yaş, ve ilaç türleri not edildi ve istatistiksel olarak karşılaştırıldı.

Bulgular: 318 hasta değerlendirildi, 157'si $(\% 49,4)$ erkek, 161'i $(\% 50,6)$ kadındı. Hastaların yaş ortalaması 72,5 idi. Beta bloker grubunun \%73'ünde cilt lezyonu yoktu. Bu oran diğer antihipertansif ajan grubu ve kullanıcı olmayan grupta sırasıyla \%39.5 ve \%21.6 idi.

Sonuç: Beta-bloker kullanan hastaların solar keratoz ve melanom dışı cilt kanseri olma olasılığı daha düşüktü. Bu retrospektif gözlem çalışmasında beta bloker tipi antihipertansif ajanların cilt kanseri gelişimine karşı koruyucu etkisi gösterilmiştir.

Anahtar Sözcükler: Beta blokör; nonmelanoma deri kanseri.

time to exposing to ultraviolet and older age, more chance to have actinic keratosis and nonmelanoma skin cancer.

Hypertension is a common health problem all over the world. Its prevalance increases with age. ${ }^{[2]}$ So that, the use of antihy-

Corresponding (illetişim): Erdinç Terzi, İstinye Üniversitesi Liv Hastanesi, Dermatoloji Kliniği, İstanbul, Turkey 
pertensive medication is higher in elderly people, and almost all patients have to continue to use them until the end of their life. This continuous use may be associated with changes in human body including cancer occurrence.

Some antihypertensive drugs related to cancer is still a matter of debate. There are blood pressure medicines that are claimed to increase or decrease the incidence of some types of cancer. In a large study, it was reported that angiotensin receptor blockers (ARB), one of the mostly used antihypertensive drugs, are linked to a small increase in cancer occurrence. ${ }^{[3]}$ In another study, relationship between cancer and use of ARBs was refused along with some other antihypertensive drugs including angiotensin converting enzyme inhibitors (ACEi), $\beta$ blockers, diuretics, and calcium channel blockers except ACEi and ARBs combinations. ${ }^{[4]}$

Beta-blockers are more involved in the cancer relationship than other antihypertensive drugs. Because beta adrenergic system may play role in cancer development leading a hypothesis that beta blocker medication may inhibit cancer progression. ${ }^{[5]}$

Several observational studies reported the protective effect of $\beta$-blockers in melanoma, multiple myeloma, breast, lung, pancreas and prostate cancers. ${ }^{[6-9]}$ An experimental animal study suggested that carvedilol, a beta blocker agent, may prevent ultraviolet exposure-related skin carcinogenesis when applied topically. ${ }^{[10]}$

In the light of these knowledges, we investigated the use of antihypertensive drugs in patients with actinic keratosis and nonmelanoma skin cancer in a small group of elderly patients in order to learn their possible effects in cancer development.

\section{Materials and Method}

This study was performed retrospectively in the dermatology outpatient clinic of Karabuk Training and Research Hospital and Istinye University Liv Hospital. The data were obtained between May 2016-June 2018. The diagnosis of solar keratoses was made by a same dermatologist clinically with a few pathologically when needed. All cancer diagnoses were put histopathologically by the pathology department of same hospital. If a patient has both solar keratosis and nonmelanoma skin cancer, patient was accepted in the nonmelanoma group. The use of antihypertensive drugs was learned from the patient data file. The study included patients over the age of fifty and who have been using medication at least for two years. Nonusers patients were admitting to the same clinic for another dermatological reason. Patients using more than one antihypertensive were classified in the beta blocker group if they use beta blocker. Gender, age, skin diagnosis and types of drugs were noted and compared with statistically. Other influencing factors such as skin type, exact duration of drug use and ultraviolet exposure were ignored in this study. Patients taking anthypertensive less than two years were accepted as nonuser.

The statistical software used was IBM SPSS 20.0 (SPSS Inc,
Chicago, IL, USA). Normality of the distribution was evaluated with Kolmogrov-Smirnov test. Numeric variables that show normal distribution were given as mean \pm standart deviation, non-numeric variables median \pm deviation and categorical variables were given as frequency. Differences between groups were evaluated with Student-t test for numeric variables that are normally distributed, and Mann Whitney $U$ test for non-numeric variables that are not normally distributed. $\mathrm{P}<0.05$ was considered sufficient for statistically significance.

\section{Results}

The files of 318 patients were assessed, 157 (49.4\%) were male, $161(50.6 \%)$ were female. Average age of patients was $72.58 \pm 6.53$.

There were 78 (24.5\%) patients on beta blocker therapy. 57 (73.1\%) of them had no skin lesion. Of the beta blocker taking patients, only one (1.2\%) patient had SCC, $7(9 \%)$ had BCC and $13(16.7 \%)$ had solar keratosis. Out of 124 (39\%) taking other antihypertensives, 3 (2.4\%) had SCC, 33 (26.6\%) had BCC, 39 (31.5\%) had solar keratosis and 49 (39.5\%) had no lesion. From $116(36.5 \%)$ patients not taking any hypertensive drug, only 25 (21.6\%) had no skin lesions while 9 (7.7\%) had SCC, 37 (31.9\%) had BCC and 45 (38.8\%) had solar keratosis.

A total of 187 (58.8\%) patients had solar keratosis, basaliomas or squamous cell carcinomas of skin. 77 (24.2\%) BCC, 13 (4.1\%) SCC and 97 (30.5\%) solar keratosis cases were diagnosed. 131 (41.2\%) cases were found to be no premalign or malign skin lesion. While only one SCC (1.2\%) case was detected in beta blocker using patients, $9 \mathrm{SCC}(7.7 \%)$ cases for nonuser group, 3 SCC (2.4\%) cases for other antihypertensive group were found. BCC and SCC. BCC, SCC and solar keratosis were seen statistically significant lower in beta blocker taking patients $(p<0.01)$ (Table 1).

There were 38 (49.3\%) female, 39 (50.7\%) male BCC cases, $52(52.5 \%)$ female, $47(47.5 \%)$ male solar keratosis cases, 4 (30.1\%) female, 9 (69.2\%) male SCC cases. 65 (50.4\%) female and $64(49.6 \%)$ male patients had no skin lesions. There was no statistically significant difference between groups regarding sex and age $(p>0.05)$. Of 22 patients using diuretics as alone or part of combination, $11(50 \%)$ had no skin lesion while remaining 11 (50\%) had only solar keratosis. They were 14 (63.3\%) males and 8 (36.7\%) females.

\section{Discussion}

Solar keratosis and nonmelanoma skin cancers are one of the major health problems of elderly people, especially in lightskinned individuals. Solar keratosis is a premalignant skin disease that can be converted to nonmelanoma skin cancers. Although these lesions do not constitute a major problem in terms of mortality, they carry importance for the quality of life and economic burden. Likewise, hypertension is more common in older age and therefore with solar keratoses and nonmelanoma skin cancers, they often overlap in the same patients. ${ }^{[11,12]}$ 
Table 1. Skin cancers and solar keratosis in the elderly hypertensive patients

\begin{tabular}{|c|c|c|c|c|c|c|}
\hline \multirow[t]{2}{*}{ Patients } & \multicolumn{2}{|c|}{$\beta$ blocker drugs } & \multicolumn{2}{|c|}{$\begin{array}{c}\text { Other antihypertensive } \\
\text { drugs }\end{array}$} & \multicolumn{2}{|c|}{$\begin{array}{c}\text { Not taking any } \\
\text { hypertensive drug }\end{array}$} \\
\hline & $\mathbf{n}$ & $\%$ & $\mathbf{n}$ & $\%$ & $\mathbf{n}$ & $\%$ \\
\hline SCC & 1 & 1.2 & 3 & 2.4 & 9 & 7.7 \\
\hline $\mathrm{BCC}$ & 7 & 9 & 33 & 26.6 & 37 & 31.9 \\
\hline Solar keratosis & 13 & 16.7 & 39 & 31.5 & 45 & 38.8 \\
\hline No skin lesions & 57 & 73.1 & 49 & 39.5 & 25 & 21.6 \\
\hline Total & 78 & 100 & 124 & 100 & 116 & 100 \\
\hline
\end{tabular}

Beta blockers are a group of drugs that are used frequently in the treatment of hypertension and arrhythmia by blocking catecholamine binding to the adrenergic receptors. ${ }^{[13]}$ In addition to cardiovascular effects, beta blockers are also beneficial in many diseases such as migraine, glaucoma, anxiety, essential tremor thyrotoxicosis and infantile hemangiomas. ${ }^{[14]}$ In recent years, anticarcinogenic properties of beta-blockers, especially propranolol, have also attracted attention. ${ }^{[15]}$ It is not surprising that beta-blockers may be involved in the treatment or prevention of cancer when it is thought that the growth and spread of tumors are also dependent on functions such as angiogenesis and adrenergic activity in cancer progression. ${ }^{[16-18]}$

Chang et al. demonstrated that both topical and oral carvedilol prevented carcinogenesis in an experimental model of epidermal hyperplasia as topical form was more effective. ${ }^{[19]}$ Carvedilol was suggested a novel chemopreventive agent in that study.

In a recent paper, Gandini et al. reported that calcium channel blockers increase nonmelanoma skin carcinomas and beta blockers increase melanoma risk. ${ }^{[2]}$ Similarly Hank et al. reported an association between beta blocker use and BCC development. ${ }^{[21]}$ However, our study showed a different outcome in this subject unlike these studies. Moreover, beta blocking agents have been suggested a beneficial effect on melanoma prognosis. ${ }^{[22,23]}$

In this study, we observed that patients using beta-blockers were less likely to have solar keratoses and nonmelanoma skin cancers. BCC was detected in only 7 of the 72 patients who have used beta blockers, 33 of the 111 patients who have used other antihypertensive drugs and 37 of the 102 patients who have not used any antihypertensive medication. The positive effect of Beta blockers on the development of BCC was statistically significant. Again, SCC was diagnosed in only 1 of the patients treated with beta blocker, 3 patients with other antihypertensive drugs and 9 of SCC in nonusers. In all patient groups, the ages were almost similar. When compared to nonusers, although the number of patients is very low, but patients on beta blocker treatment seems to have less SCC.

Precancereous solar keratosis appeared as similar number in all three groups. It can be argued that beta blockers might have prevented or slowed the conversion to malignancy at this stage. Skin lesions were generally more in nonusers than in antihypertensive drug users. Although this difference is remarkable in beta blocking agent users, other antiypertensives seemed more benefical than nonusers for preventing SCC. Could it be hypothesized that hypertension itself has a protective effect on development of SCC?

Due to photosensitizing properties, diuretics were thought as potential inducers of SCC. ${ }^{[2]} 11$ from 22 diuretic using patients had no lesion while remaining 11 had solar keratosis. No malignant skin lesion was noted. As compared with nonusers who have 82 solar keratosis and nonmelanoma out of 102 patients, there seems no inducing solar keratosis in diuretic using patients. There was no difference between female patients and male patients in terms of skin lesions and drug use.

The major factors in the development of skin cancers are skin type, ultraviolet exposure and advanced age. As the UV exposure is prolonged and the skin type is faired, pale and freckled, the incidence of solar keratosis, melanoma and nonmelanoma skin cancers increases. ${ }^{[25]}$ This feature of the patients was not considered in the study. It is one of the main limitations of this research.

As a summary, despite there are conflicting reports about antiypertensive medication on cancer risk, we modestly demonstrated the favorable effect of beta blockers in elderly patients. However, we believe that our observations, although based on small numbers and with its flaws, would trigger larger trials.

Conflict of interest: There are no relevant conflicts of interest to disclose.

\section{References}

1. Schmitt JV, Miot HA. Actinic keratosis: a clinical and epidemiological revision. An Bras Dermatol. 2012;87,425-34.

2. Sun Z. Aging, arterial stiffness, and hypertension. Hypertension. 2015;65,252-6.

3. Sipahi I, Debanne SM, Rowland DY, et al. Angiotensin-receptor blockade and risk ofcancer: meta-analysis of randomised controlled trials. Lancet Oncol. 2010;11,627-36.

4. Bangalore S, Kumar S, Kjeldsen SE, et al. Antihypertensive drugs and risk of cancer: network meta-analyses and trial sequential analyses of 324,168 participants from randomised trials. Lancet Oncol. $2011 ; 12,65-82$. 
5. Akbar S, Alsharidah MS. Are beta blockers new potential anticancer agents? Asian Pac J Cancer Prev. 2014;15,9567-74.

6. Melhem-Bertrandt A, et al. Beta-blocker use is associated with improved relapse-free survival in patients with triple-negative breast cancer. J Clin Oncol. 2011;29,2645-52.

7. De Giorgi V, Gandini S, Grazzini $M$, et al. $\beta$-blockers: a new and emerging treatment for melanoma. Recenti Prog Med. 2012;103,11-6.

8. Hwa YL, Shi Q, Kumar SK, Lacy MQ, et al. Beta-blockers improve survival outcomes in patients with multiple myeloma: a retrospective evaluation. Am J Hematol. 2017;92,50-55.

9. Grytli HH, Fagerland MW, Fosså SD, et al. Use of $\beta$-blockers is associated with prostate cancer specific survival in prostate cancer patients on androgen deprivation therapy. Prostate, 2013;73,250607.

10. Huang KM, et al. Topically Applied Carvedilol Attenuates Solar UItraviolet Radiation Induced Skin Carcinogenesis. Cancer Prev Res (Phila). 2017;10,598-606.

11. Joel L. Cohen. Actinic Keratosis Treatment as a Key Component of Preventive Strategies for Nonmelanoma Skin Cancer.J Clin Aesthet Dermatol. 2010;3, 39-44.

12. Robles NR, Macias JF. Hypertension in the elderly. Cardiovasc Hematol Agents Med Chem. 2015;12,135.

13. Weir MR. Beta-blockers in the treatment of hypertension: are there clinically relevant differences? Postgrad. 2009;121:90-8.

14. Akbar S, Alorainy MS. The current status of beta blockers' use in the management of hypertension. Saudi Med J. 2014;35,1307-17.

15. Pantziarka P, Bouche G, Sukhatme V, et al. Repurposing Drugs in Oncology (ReDO)-Propranolol as an anti-cancer agent. E cancer medical science. 2016;12,10,680.

16. He JJ et al. Activation of $\beta$-adrenergic receptor promotes cellular proliferation in human glioblastoma. Oncol Lett. 2017;14,38463852.

17. Lin X, Luo K, Lv Z, Huang J. $\beta$-adrenoceptor action on pancreatic cancer cell proliferation and tumor growth in mice. Hepatogastroenterology. 2012;59,584-8.

18. Hondermarck H, Jobling P. The Sympathetic Nervous System Drives Tumor Angiogenesis. Trends Cancer. 2018;4,93-94.

19. Chang A, et al. Prevention of skin carcinogenesis by the $\beta$-blocker carvedilol. Cancer Prev Res (Phila). 2015;8,27-36.

20. Gandini S, et al. Anti-hypertensive drugs and skin cancer risk: a review of the literature and meta-analysis. Crit Rev Oncol Hematol. 2018;122:1-9.

21. Hank et al. Use of antihypertensive drugs and risk of keratinocyte carcinoma: A meta-analysis of observational studies Pharmacoepidemiol Drug Saf. 2018;27,279-288.

22. De Giorgi V, Grazzini M, Gandini S, et al. Treatment with $\beta$-blockers and reduced disease progression in patients with thick melanoma. Arch Intern Med. 2011;171,779-81.

23. Lemeshow S, Sorensen HT, Phillips $G$, et al. $\beta$-Blockers and survival among Danish patients with malignant melanoma: a population-based cohort study. Cancer Epidemiol Biomarkers Prev. 2011;20,2273-9.

24. de Vries E, Trakatelli M, Kalabalikis D, et al. Known and potential new risk factors for skin cancer in European populations: a multicentre case-control study. Br J Dermatol. 2012;167 (Suppl 2),1-13.

25. Lai V, Cranwell W, Sinclair R. Epidemiology of skin cancer in the mature patient. Clin Dermatol. 2018;36,167-176. 